\title{
ANALISIS SPASIAL INDEKS KEKERINGAN DI DAERAH ALIRAN SUNGAI (DAS) KAMPAR PROVINSI RIAU
}

\author{
(Spatial Analysis of Drought Index in Kampar Watershed Riau Province)
}

\author{
Novreta Ersyi Darfia ${ }^{1}$, Widdya Rahmalina ${ }^{2}$ \\ ${ }^{1}$ Program Studi Teknik Sipil Universitas Abdurrab \\ ${ }^{2}$ Program Studi Teknik Informatikal Universitas Abdurrab \\ E-mail: novreta@univrab.ac.id
}

\begin{abstract}
ABSTRAK
Pemanasan global telah meningkatkan frekuensi dan intensitas peristiwa iklim ekstrem seperti kekeringan. Penanggulangan untuk mengurangi dampak yang ditimbulkan oleh kekeringan perlu dilakukan. Akan tetapi informasi mengenai kekeringan lahan masih kurang untuk saat ini. Informasi mengenai kondisi keadaan permukaan diperlukan baik dalam bentuk data numerik maupun data spasial. Seiring dengan kemajuan teknologi, informasi spasial suatu wilayah dapat dilakukan dengan mudah. Sistem informasi geografis memiliki kemampuan yang sangat baik dalam memvisualisasikan data spasial berikut atribut-atributnya. Penelitian ini bertujuan untuk memetakan sebaran indeks kekeringan di Daerah Aliran Sungai (DAS) Kampar Provinsi Riau. Diharapkan dengan penelitian ini dapat memberikan informasi spasial penyebaran indeks kekeringan sehingga dapat diambil tindakan untuk menghindari atau mengurangi dampak dari kekeringan tersebut. Terdapat dua analisis utama yang dilakukan pada penelitian ini, yaitu analisis indeks kekeringan menggunakan metode KBDI dan analisis spasial indeks kekeringan metode KBDI tersebut. Analisis spasial menunjukkan hasil bahwa sifat kekeringan di lokasi penelitian didominasi oleh sifat "Sedang". Kekeringan dengan kategori "Tinggi" dimulai pada bulan Juni dan berakhir di bulan September dengan sebaran kekeringan "Tinggi" terbesar terjadi pada bulan Juli dan Agustus. Pada DAS Kampar tidak terjadi kekeringan "Ekstrim". Kekeringan dengan kategori "Rendah" terjadi pada bulan November dan Desember.
\end{abstract}

Kata Kunci: Indeks Kekeringan, DAS Kampar, KBDI, Analisis Spasial

\begin{abstract}
Global warming has increased the frequency and intensity of extreme climate events such as drought. Mitigation to reduce the impact caused by drought needs to be done. However, information about land drought is still lacking at this time. Information about surface conditions is needed both in the form of numerical data and spatial data. Along with technological advances, a spatial information area can be done easily. Geographical information systems have a very good ability to visualize spatial data and its attributes. This study aims to map the distribution of drought indices in the Kampar River Basin (DAS) of Riau Province. It is hoped that this research can provide spatial information on the spread of drought indexes so that action can be taken to avoid or reduce the impact of such drought. There are two main analyzes conducted in this study, namely the analysis of the drought index using the $K B D I$ method and the spatial analysis of the drought index of the KBDI method. Spatial analysis shows the results that the nature of drought at the study site is dominated by the nature of "Medium". The "High" drought began in June and ended in September with the largest "High" drought occurring in July and August. In the Kampar watershed there is no "Extreme" drought. Drought in the category of "Low" occurred in November and December.
\end{abstract}

Keywords: Drought Index, Kampar Watershed, KBDI, Spatial Analysis 


\section{PENDAHULUAN}

Pemanasan global telah meningkatkan frekuensi dan intensitas peristiwa iklim ekstrem seperti kekeringan $(\mathrm{Wu}$, et al., 2016). Definisi kekeringan yang paling sederhana adalah kekurangan air untuk memenuhi kebutuhan. Namun, konsep kekeringan jauh lebih kompleks karena kebutuhan ini bervariasi antar sektor (Gibson, et at., 2019). Kekeringan adalah periode kering yang tidak normal dan berkepanjangan ketika jumlah air yang tersedia tidak mencukupi untuk memenuhi penggunaan normal (DFES, 2014).

Kejadian bencana di Indonesia dari tahun 2001 hingga 2018, 98\% nya adalah bencana hidrometeorologi yang dapat dipengaruhi oleh perubahan iklim. Salah satu bencana hidrometeorologis tersebut adalah kekeringan (BNPB, 2018). Oleh karena itu, estimasi tingkat keparahan, luas spasial, dan frekuensi kekeringan adalah salah satu elemen kunci untuk perencanaan dan manajemen sumber daya air (Kwak, et al., 2016).

Provinsi Riau adalah salah satu daerah di Indonesia yang terletak pada garis khatulistiwa dimana temperatur yang diakibatkan panas sinar matahari lebih tinggi dan lebih lama bila dibandingkan dengan daerah yang jauh dari garis khatulistiwa. Provinsi Riau merupakan salah satu provinsi yang rawan kebakaran di Indonesia yang mengalami kejadian kebakaran hutan dan lahan setiap tahunnya. Kerusakan hutan di Riau merupakan yang paling menjadi sorotan di Indonesia bahkan dunia. Berdasarkan deteksi Satelit NOAA 18 Tahun 2013, terlihat bahwa Provinsi Riau memiliki titik hotspot yang lebih besar dibandingkan provinsi lain di Indonesia. Setiap tahunnya Riau menghasilkan kabut yang disebabkan kebakaran hutan dan lahan (Darfia, 2016).

Penanggulangan untuk mengurangi dampak yang ditimbulkan oleh kekeringan perlu dilakukan. Akan tetapi informasi mengenai kekeringan lahan masih kurang untuk saat ini. Padahal informasi tersebut sangat dibutuhkan oleh berbagai pihak. Informasi kekeringan lahan dapat membantu masyarakat sekitar untuk mengetahui potensi kekeringan pada daerahnya, sehingga masyarakat dapat melakukan tindakan yang dapat meminimalkan dampak kekeringan tersebut. Karena bisa jadi kekeringan terjadi karena kebiasaan buruk yang dilakukan oleh masyarakat. Sedangkan untuk pemerintah, informasi ini bisa dijadikan sebagai acuan untuk pengambilan tindakan untuk menghindari atau mengurangi dampak kekeringan tersebut (Aprilliyanti dan Zainuddin, 2017).

Informasi mengenai kondisi keadaan permukaan diperlukan baik dalam bentuk data numerik maupun data spasial. Seiring dengan kemajuan teknologi, informasi spasial suatu wilayah dapat dilakukan dengan mudah. Sistem informasi geografis memiliki kemampuan yang sangat baik dalam memvisualisasikan data spasial berikut atribut-atributnya (Raharjo, 2010).

Penelitian ini bertujuan untuk memetakan sebaran indeks kekeringan di Daerah Aliran Sungai (DAS) Kampar
Provinsi Riau. Diharapkan dengan penelitian ini dapat memberikan informasi spasial penyebaran indeks kekeringan sehingga dapat diambil tindakan untuk menghindari atau mengurangi dampak dari kekeringan tersebut.

\section{Indeks Kekeringan}

Indeks kekeringan merupakan suatu perangkat utama untuk mendeteksi, memantau, dan mengevaluasi kejadian kekeringan. Kekeringan memiliki karakter multi-disiplin yang membuat tidak adanya sebuah definisi yang dapat diterima oleh semua pihak di dunia. Demikian pula tidak ada sebuah indeks kekeringan yang berlaku universal (Niemeyer, 2008).

Berdasarkan penelitian untuk indeks kekeringan, hampir semua indeks kekeringan menggunakan curah hujan baik secara tunggal atau dalam kombinasi dengan unsurunsur meteorologi lainnya, tergantung pada jenis kebutuhan yang juga disarankan oleh WMO (1975). Misalnya, kombinasi variabel hidrometeorologi meliputi: suhu dan curah hujan (Indeks KBDI) atau hanya curah hujan (SPI) dan Teori Run.

Kekeringan dapat dipisahkan menjadi empat kategori besar yaitu kekeringan meteorologi, hidrologi, pertanian, dan sosial ekonomi (van Dijk, et al., 2013). Kekeringan tersebut yaitu (Wilhite dan Buchanan-Smith 2005):

a. Kekeringan meteorologis ditandai oleh situasi di mana curah hujan jauh lebih rendah daripada curah hujan yang diperkirakan secara klimatologis di wilayah yang luas

b. Kekeringan pertanian ditandai oleh kurangnya kelembaban di zona akar tanaman dan tidak hanya bergantung pada jumlah curah hujan. Jumlah curah hujan yang sama di bulan Januari dan Juli akan memiliki dampak yang berbeda. Kekeringan yang terjadi di musim dingin mungkin memiliki sedikit atau tidak ada efek yang dapat diamati pada tanaman. Namun, selama musim panas, ketika suhu lebih hangat dan hari-hari lebih lama, tanaman akan mengambil lebih banyak air dari zona akar. Akibatnya, kekeringan musim panas lebih jelas dan menyebabkan lebih banyak kerusakan. Kekeringan sedang selama periode pertumbuhan tanaman dapat menyebabkan pertumbuhan tanaman terhambat dan hasil panen berkurang. Kekeringan parah selama periode yang sama dapat menyebabkan kegagalan panen total.

c. Kekeringan hidrologis ditandai dengan menurunnya aliran di sungai dan sungai dan permukaan air di bawah rata-rata di danau, waduk, dan air tanah.

d. Kekeringan sosio-ekonomi berbeda dari jenis-jenis lainnya karena kekeringan ini mengaitkan penawaran dan permintaan barang-barang ekonomi (mis., Air, bijibijian, tenaga hidro-listrik) dengan unsur-unsur kekeringan meteorologis, hidrologi, atau pertanian. 


\section{Analisis Kekeringan Menggunakan Keetch-Byram Drought Index (KBDI)}

Indeks kekeringan adalah jumlah yang mewakili pengaruh bersih (net) evapotranspirasi dan presipitasi dalam menghasilkan defisiensi kelembaban kumulatif pada serasah tebal atau lapisan tanah bagian atas. Indeks kekeringan merupakan jumlah yang berkaitan dengan daya nyala (flammability) bahan-bahan organik pada tanah (Keetch dan Byram, 1988).

Model KBDI dibuat berdasarkan asumsi-asumsi berikut ini (Keetch and Byram, 1968):

a. Laju hilangnya kelembaban di daerah kawasan hutan akan bergantung pada kerapatan vegetasi yang menutupi kawasan tersebut. Pada gilirannya, kerapatan vegetasi yang menutupi dan kapasitas penguapannya, merupakan fungsi dari nilai rata-rata curah hujan tahunan. Selanjutnya, vegetasi tersebut pada akhirnya akan menyesuaikan dengan sendirinya dalam memanfaatkan lebih banyak kelembaban di sekitarnya.

b. Hubungan vegetasi dengan curah hujan mendekati kurva eksponensial dimana laju hilangnya kelembaban merupakan fungsi dari rata-rata curah hujan tahunan. Oleh karena itu, laju hilangnya kelembaban akan menurun dengan semakin menurunnya kerapatan vegetasi, dan dengan menurunnya rata-rata curah hujan tahunan.

c. Laju hilangnya kelembaban dari tanah ditentukan oleh hubungan evapotranspirasi.

d. Hilangnya kelembaban tanah seiring dengan waktu diperkirakan dengan bentuk kurva eksponensial dimana kelembaban titik layu digunakan sebagai tingkat kelembaban yang terendah. Oleh karena itu, laju penurunan (drop) yang diharapkan pada kelembaban tanah terhadap titik layu pada kondisi yang sama, adalah cukup proporsional terhadap jumlah ketersediaan air dalam lapisan tanah untuk waktu tertentu.

e. Kedalaman lapisan tanah pada saat kekeringan berlangsung adalah saat dimana tanah memiliki nilai kapasitas lapang sebesar $20 \mathrm{~cm}$. Meskipun seleksi 20 $\mathrm{cm}$ agak berubah-ubah, namun nilai numerik yang tepat tidak begitu penting. Kadar kelembaban yang terjadi pada kapasitas lapang $20 \mathrm{~cm}$ tersebut cukup masuk akal untuk penggunaan pengendalian kebakaran hutan sebab di banyak negara, permukaan vegetasi menguapkan banyak air seluruhnya terjadi pada musim panas.

f. KBDI hanya memerlukan data-data seperti rata-rata curah hujan tahunan, curah hujan harian, dan temperatur harian maksimum yang kesemuanya tersedia di stasiun pengamat cuaca.

Kelebihan KBDI antara lain (Deeming 1995):

a. KBDI dikembangkan di Amerika Serikat pada tahun 1968 dan telah diterapkan penggunaannya dengan beberapa modifikasi yang dilakukan oleh orang-orang Australia dan negara lain. Di Indonesia KBDI telah diterapkan oleh IFFM (Integrated Forest Fire Management), lembaga kerja sama Jerman dan Indonesia, di Kalimantan Timur dengan KBDI sistem metrik.

b. KBDI hanya membutuhkan data curah hujan 24 jam, temperatur maksimum 24 jam, dan rata-rata curah hujan tahunan yang diperoleh dari stasiun pengamat cuaca.

c. KBDI dapat dihitung secara manual dan persamaan hitungnya cukup mudah untuk diprogram ke dalam kalkulator maupun komputer.

d. Instrumen yang diperlukan dalam stasiun pengamat cuaca adalah catatan pengukur curah hujan, termograf, dan instrumen pelindung.

e. KBDI harus dihitung setiap saat dilakukan pengamatan cuaca, namun tidak harus dihitung tiap hari. Oleh karena itu dapat dihitung sekali dalam seminggu.

Tabel 1. Klasifikasi Skala Nilai KBDI (Keetch and Byram,

\begin{tabular}{cc}
\multicolumn{2}{c}{ 1968) } \\
\hline Nilai KBDI & Kategori \\
\hline $0-999$ & Rendah \\
$1000-1499$ & Sedang \\
$1500-1749$ & Tinggi \\
$1750-2000$ & Ekstrim \\
\hline
\end{tabular}

Indeks kekeringan ini menggambarkan tingkat/nilai defisiensi kelembaban tanah dan lahan yang dihitung berdasarkan data cuaca harian. Untuk menghitung KBDI diperlukan beberapa data yaitu:

Data curah hujan rata-rata tahunan

Curah hujan harian

Temperatur harian maksimum

Cara perhitungan metode ini didasarkan pada persamaan sebagai berikut:

KBDI hari ini $=\left(\Sigma \mathrm{KBDI}\right.$ kemarin- $\left(10^{*} \mathrm{CH}\right)+\mathrm{DF}$ hari ini Keterangan :

$\mathrm{CH}$ : Curah Hujan Bersih

DF : Faktor kekeringan yang telah dimodifikasi dan dapat digunakan untuk perkiraan bahaya kebakaran adalah, dengan formulasi sebagai berikut:

$$
D F=\frac{(2000-Y K B D I) \times\left(0.9676 \times \operatorname{EXP}\left(0.0875 \times T_{\max }+1.552\right)-8.229\right) \times 0.001}{(1+10.88 \times \operatorname{EXP}(-0.00175 \times \text { Annual }))}
$$

Keterangan:

YKBDI : Indeks kekeringan kemarin

$T_{\max }$

Annual
: Suhu maksimum $\left({ }^{\circ} \mathrm{C}\right)$

: Rata-rata curah hujan tahunan $(\mathrm{mm})$
Awal perhitungan KBDI untuk setiap stasiun hujan tidak selalu sama, karena awal perhitungan dimulai dengan penetapan indeks kekeringan yang bernilai nol yaitu pada saat satu hari setelah masa hujan dengan curah hujan sebanyak 150-200 mm dalam satu minggu (Keetch and Byram, 1968). 


\section{Analisis Spasial}

Analisis spasial adalah sekumpulan teknik yang dapat digunakan dalam pengolahan data Sistem Informasi Geografis (SIG). Analisis spasial juga dapat diartikan sebagai teknik-teknik yang digunakan untuk meneliti dan mengeksplorasi data dari perspektif keruangan. Semua teknik atau pendekatan perhitungan matematis yang terkait dengan data keruangan (spasial) dilakukan dengan fungsi analisis spasial tersebut.

Pengelolaan data spasial merupakan hal yang penting dalam pengelolaan data Sistem Informasi Geografi. Proses pengolahan dilakukan dengan menerapkan kaidah-kaidah relasional terkait secara simultan. Sistem Informasi Geografis (SIG) tidak hanya berfungsi untuk memindahkan / mentransformasi peta konvensional (analog) ke bentuk digital (digital map), lebih jauh lagi sistem ini mempunyai kemampuan untuk mengolah dan menganalisis data yang mengacu pada lokasi geografis menjadi informasi berharga (Ningsih, 2005)

Sistem Informasi Geografis (SIG) adalah suatu kumpulan terorganisasi yang terdiri dari perangkat keras, perangkat lunak, data geografis, dan personil yang didesain untuk memperoleh, menyimpan, memperbaiki, memanipulasi, menganalisis, dan menampilkan semua bentuk informasi yang bereferensi geografis (ESRI 1990). Lebih lanjut Arronof (1989) juga mengatakan SIG sebagai sebuah sistem komputerisasi yang memfasilitasi fase entri data, analisis data, dan presentasi data yang terutama berkenaan dengan data yang memiliki georeferensi.

Karakteristik utama Sistem Informasi Geografi adalah kemampuan menganalisis sistem seperti analisa statistik dan overlay yang disebut analisa spasial. Analisa dengan menggunakan Sistem Informasi Geografi yang sering digunakan dengan istilah analisa spasial, tidak seperti sistem informasi yang lain yaitu dengan menambahkan dimensi 'ruang (space)' atau geografi. Kombinasi ini menggambarkan attribut-attribut pada bermacam fenomena seperti umur seseorang, tipe jalan, dan sebagainya, yang secara bersama dengan informasi seperti dimana seseorang tinggal atau lokasi suatu jalan (Keele,1997).

Sistem Informasi Geografi mempunyai keistimewaan analisa yaitu analisa overlay dan analisa proximity dimana analisa overlay merupakan proses integrasi data dari lapisan-lapisan yang berbeda sedangkan analisa proximity merupakan analisa geografis yang berbasis pada jarak antar layer. Analisa spasial dilakukan dengan meng-overlay dua peta yang kemudian menghasilkan peta baru hasil analisis. Data Spasial merupakan data yang menunjuk posisi geografi dimana setiap karakteristik memiliki satu lokasi yang harus ditentukan dengan cara yang unik. Untuk menentukan posisi secara absolut berdasar sistem koordinat. Untuk area kecil, sistem koordinat yang paling sederhana adalah grid segiempat teratur. Untuk area yang lebih besar, berdasarkan proyeksi kartografi yang umum digunakan (Ningsih, 2005).
Pemetaan dan analisis spasial banyak digunakan dalam berbagai bidang kajian. Penggunaan keduanya semakin meningkat dengan berkembangnya ilmu dan teknologi yang berkaitan erat dengan pemetaan dan analisis spasial. Ilmu dan teknologi yang dimaksud adalah penginderaan jauh (remote sensing), global positioning system (GPS) dan sistem informasi geografis (geographic information system) atau SIG. Integrasi pemetaan dan analisis spasial dengan memanfaatkan teknologi penginderaan jauh, GPS dan SIG banyak digunakan dalam kajian secara komprehensif tentang potensi sumberdaya yang terdapat di suatu wilayah (Susilo, 2012)

Sistem Informasi Geografis (SIG) dirancang untuk menangkap, memanipulasi, menyimpan, menganalisis, dan mengelola data. Ini adalah perkembangan dari kartografi (ilmu membuat peta) dan memungkinkan individu untuk memvisualisasikan, menganalisis, mempertanyakan, dan menafsirkan data. Pihak yang tertarik dapat menggunakan GIS untuk memahami hubungan, tren, dan pola dengan lebih baik (Tate, 2018)

Fungsi dari analisis spasial yaitu (Prahasta, 2009):

a. Klasifikasi (reclassify), yaitu suatu kegiatan yang mengklasifikasikan kembali suatu data hingga pada akhirnya menjadi sebuah data spasial yang baru dan berdasarkan pada kriteria atau atribut tertentu.

b. Jaringan atau network, yaitu sebuah fungsionalitas yang merujuk pada data-data spasial, titik-titik, ataupun garis-garis sebagai jaringan yang tidak terpisahkan.

c. Overlay, merupakan fungsionalitas yang menghasilkan layer data spasial baru, di mana layer tersebut merupakan hasil dari kombinasi minimal dua layer yang menjadi masukkannya.

d. Buffering, adalah fungsi yang akan menghasilkan layer spasial baru dengan bentuk poligon serta memiliki jarak tertentu dari unsur-unsur spasial yang menjadi masukkannya.

e. 3D analysis, fungsi ini terdiri atas sub-sub fungsi yang berkaitan dengan presentasi data spasial yang terdapat di dalam ruang 3 dimensi atau permukaan digital.

f. Digital Image Processing, untuk fungsionalitas ini nilai ataupun intensitas dianggap sebagai fungsi sebar atau spasial.

\section{METODOLOGI}

Data curah hujan merupakan komponen utama dalam menganalisa indeks kekeringan. Data yang diperlukan adalah data seri dengan panjang data yang cukup panjang. Data yang digunakan pada penelitian ini adalah data hujan pada stasiun hujan yang berada di sekitar Daerah Aliran Sungai (DAS) Kampar. Stasiun-stasiun tersebut yaitu Stasiun Batu Bersurat, Gema, Kemang, Koto Baru, Lipat Kain, Lubuk Ogung, Muara Lembu, Pantai Raja, Pasar Kampar, Silam, Sorek, Keritang, Usul, Lubuk Ramo, Tembilahan, Sentajo, Lubuk Kebun, Talang Jerinjing, Pangkalan Kasai, Air Molek, Lubuk Bendahara, dan Ujung Batu dengan panjang data 15 tahun (2004 2018). 
Analisis indeks kekeringan metode KBDI selain 15 tahun (2004-2018).

memerlukan data hujan juga memerlukan data suhu.

Data yang digunakan pada penelitian ini adalah data

klimatologi pada stasiun klimatologi di sekitar DAS

Kampar, yaitu Stasiun Koto Baru, Pasar Kampar,

Sentajo, Air Molek, dan Lubuk Bendahara dengan kekeringan metode KBDI tersebut Gambar 1 adalah panjang data sama dengan data hujan yaitu data selama tahapan dalam penyelesaian penelitian ini.

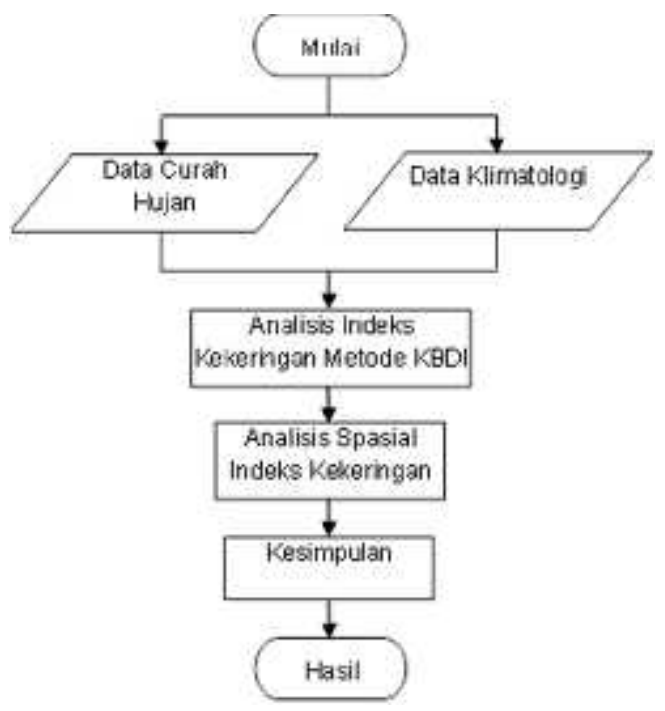

Gambar 1. Bagan Alir Penelitian

\section{HASIL DAN PEMBAHASAN}

\section{Analisis Indeks Kekeringan Metode Keetch Byram Drought Index (KBDI)}

Indeks kekeringan dengan metode KBDI menghasilkan kekeringan harian pada lokasi studi. Awal perhitungan dimulai dengan penetapan indeks kekeringan yang bernilai nol yaitu pada saat satu hari setelah masa hujan dengan curah hujan sebanyak 150-200 mm dalam satu minggu (Keetch dan Byram, 1968). Setelah didapat indeks kekeringan Keetch Byram harian, dihitung indeks kekeringan bulanan dari indeks kekeringan harian tersebut yaitu dengan mencari rataannya yang merupakan indeks kekeringan Keetch Byram bulanan. Skala yang dihasilkan dari perhitungan KBDI ini berada di antara 0 sampai dengan 2000. Sifat tingkat kekeringan KBDI dibagi ke dalam empat kelompok, yaitu rendah, sedang, tinggi, dan ekstrim.

Data yang digunakan pada perhitungan KBDI ini adalah data mulai dari tanggal 1 Januari 2004 sampai dengan 31 Desember 2018. Awal perhitungan KBDI untuk setiap stasiun hujan tidak selalu sama, karena awal perhitungan dimulai dengan penetapan indeks kekeringan yang bernilai nol yaitu pada saat satu hari setelah masa hujan dengan curah hujan sebanyak 150-200 mm dalam satu minggu.

Tabel 2. Contoh Tabel Perhitungan KBDI

\begin{tabular}{|c|c|c|c|c|c|c|c|c|c|}
\hline Tanggal & $\mathrm{CH}$ & $\mathrm{T}_{\text {maks }}$ & $\mathrm{KBDl}$ & $\mathrm{CH}_{\text {het }}$ & Annual & $\mathrm{KBDl}-\left(10^{*} \mathrm{CH}_{\text {net }}\right)$ & $\mathrm{DF}$ & $\mathrm{KBDh}$ & Sifat \\
\hline & & & & & & & & & \\
\hline & & & & & & & & & \\
\hline & & & & & & & & & \\
\hline & & & & & & & & & \\
\hline & & & & & & & & & \\
\hline & & & & & & & & & \\
\hline & & & & & & & & & \\
\hline & & & & & & & & & \\
\hline & & & & & & & & & \\
\hline & & & & & & & & & \\
\hline
\end{tabular}




\section{Keterangan:}

[1] Tanggal

[2] $\mathrm{CH}=$ curah hujan harian

[3] $\mathrm{T}_{\text {maks }}=$ suhu maksimum harian

[4] $\mathrm{KBDly}=$ nilai dari [9] hari sebelumnya

[5] $\mathrm{CH}_{\text {net }}=$ nilai curah hujan bersih

$=[2]-5$ (diasumsikan evapotranspirasi adalah $5 \mathrm{~mm}$ )

[6] Annual = hujan tahunan

[7] $\mathrm{KBDly}-\left(10^{*} \mathrm{CH}\right.$ net $)=[4]-\left(10^{*}[5]\right)$ Apabila hasilnya $<0$, maka

[8] $\mathrm{KBDIY}-\left(10^{*} \mathrm{CHnet}\right)=0$

$D F=\frac{(2000-K \quad r) \times\left(0.9676 \times \operatorname{EXP}\left(0.0875 \times T_{\max }+1.552\right)-8.229\right) \times 0.001}{(1+10.88 \times \operatorname{EXP}(-0.00175 \times \text { Annual }))}$

[9] $\mathrm{KBDIT}_{\mathrm{T}}=[7]+[8]$

[10] Sifat Kekeringan

Untuk contoh perhitungan, dilakukan perhitungan untuk Stasiun Hujan Batu Bersurat. Perhitungan dimulai pada tanggal 21 Februari 2004, dimana jumlah hujan selama seminggu sebelumnya adalah $158 \mathrm{~mm}(>150 \mathrm{~mm})$. Selanjutnya ditetapkan bahwa nilai $\mathrm{KBDIT}_{\mathrm{T}}[9]$ adalah 0 (nol).
Maka indeks kekeringan pada tanggal 22 Februari 2004 adalah:

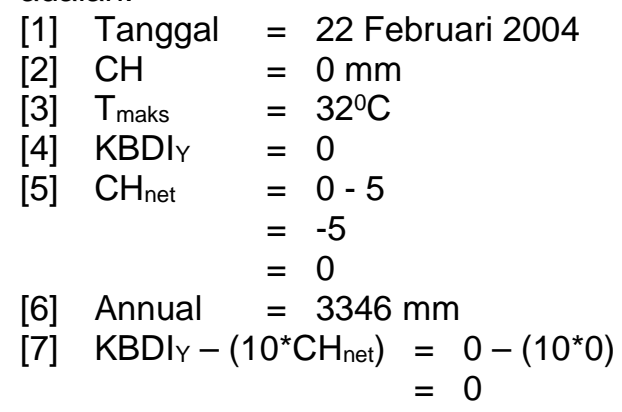

[8]

$$
\begin{aligned}
& D F=\frac{(2000-K \quad r) \times\left(0.9676 \times \operatorname{EXP}\left(0.0875 \times T_{\max }+1.552\right)-8.229\right) \times 0.001}{(1+10.88 \times \operatorname{EXP}(-0.00175 \times \text { Annual }))} \\
& D F=\frac{(2000-0) \times(0.9676 \times \operatorname{EXP}(0.0875 \times 32+1.552)-8.229) \times 0.001}{(1+10.88 \times \operatorname{EXP}(-0.00175 \times 3346))} \\
& \mathrm{DF}=129,736 \\
& \text { [9] } \mathrm{KBDIT}=0+129,736 \\
& =129,736
\end{aligned}
$$

\begin{tabular}{|c|c|c|c|c|c|c|c|c|c|}
\hline Tanggal & $\mathrm{CH}$ & $T_{\text {maks }}$ & $\mathrm{KBDl}_{\mathrm{Y}}$ & $\mathrm{CH}_{\text {net }}$ & Annual & $\mathrm{KBDl}_{\mathrm{Y}}-\left(10^{*} \mathrm{CH}_{\mathrm{net}}\right)$ & $\mathrm{DF}$ & $\mathrm{KBDh}$ & Sifat \\
\hline 1-Feb-04 & 18 & 33,5 & & & & & & & \\
\hline 2-Feb-04 & 0 & 33,5 & & & & & & & \\
\hline 3-Feb-04 & 0 & 33,0 & & & & & & & \\
\hline 4-Feb-04 & 0 & 31,5 & & & & & & & \\
\hline 5-Feb-04 & 12 & 35,5 & & & & & & & \\
\hline 6-Feb-04 & 0 & 33,0 & & & & & & & \\
\hline 7-Feb-04 & 0 & 32,0 & & & & & & & \\
\hline 8-Feb-04 & 12 & 32,0 & & & & & & & \\
\hline 9-Feb-04 & 2 & 34,5 & & & & & & & \\
\hline 10-Feb-04 & 0 & 33,5 & & & & & & & \\
\hline 11-Feb-04 & 0 & 31,0 & & & & & & & \\
\hline 12-Feb-04 & 23 & 34,0 & & & & & & & \\
\hline 13-Feb-04 & 0 & 32,5 & & & & & & & \\
\hline 14-Feb-04 & 0 & 33,0 & & & & & & & \\
\hline 15-Feb-04 & 0 & 32,0 & & & & & & & \\
\hline 16-Feb-04 & 0 & 35,0 & & & & & & & \\
\hline 17-Feb-04 & 0 & 32,5 & & & & & & & \\
\hline 18-Feb-04 & 54 & 33,5 & & & & & & & \\
\hline 19-Feb-04 & 71 & 32,5 & & & & & & & \\
\hline 20-Feb-04 & 0 & 31,5 & & & & & & & \\
\hline 21-Feb-04 & 33 & 31,5 & & & & & & 0,000 & \\
\hline 22-Feb-04 & 0 & 32,0 & 0,000 & 0,000 & 3346,000 & 0,000 & 129,736 & 129,736 & RENDAH \\
\hline 23-Feb-04 & 0 & 34,0 & 129,736 & 0,000 & 3346,000 & 129,736 & 147,376 & 277,112 & RENDAH \\
\hline 24-Feb-04 & 20 & 34,5 & 277,112 & 15,000 & 3346,000 & 127,112 & 142,450 & 269,562 & RENDAH \\
\hline 25-Feb-04 & 8 & 35,0 & 269,562 & 3,000 & \begin{tabular}{|l|}
3346,000 \\
\end{tabular} & 239,562 & 150,090 & 389,652 & RENDAH \\
\hline 26-Feb-04 & 8 & 34,5 & 389,652 & 3,000 & 3346,000 & 359,652 & 133,145 & 492,796 & RENDAH \\
\hline 27-Feb-04 & 0 & 34,0 & 492,796 & 0,000 & 3346,000 & 492,796 & 118,767 & 611,564 & RENDAH \\
\hline 28-Feb-04 & 0 & 36,0 & 611,564 & 0,000 & 3346,000 & 611,564 & 132,452 & 744,015 & RENDAH \\
\hline 29-Feb-04 & 0 & 32,5 & 744,015 & 0,000 & 3346,000 & 744,015 & 85,565 & 829,580 & RENDAH \\
\hline
\end{tabular}

[10] Sifat Kekeringan = Rendah

Hasil perhitungan selanjutnya dapat dilihat pada Tabel 3 berikut.

Tabel 3. KBDI Stasiun Hujan Batu Bersurat

Setelah didapat indeks kekeringan Keetch Byram harian, dihitung indeks kekeringan bulanan dari indeks kekeringan harian tersebut yaitu dengan mencari rataannya yang merupakan indeks kekeringan Keetch Byram bulanan. Hasilnya adalah seperti pada Tabel 4 dan untuk sifat kekeringannya dapat dilihat pada Tabel 5. 
Tabel 4. KBDI Bulanan Stasiun Hujan Batu Bersurat

\begin{tabular}{|c|c|c|c|c|c|c|c|c|c|c|c|c|}
\hline Tahun & Jan & Feb & Mar & Apr & Mei & Jun & Jul & Agu & Sep & Okt & Nov & Des \\
\hline 2004 & & 468,0 & 1324,2 & 565,4 & 1055,4 & 1560,3 & 1390,6 & 1550,2 & 1587,7 & 1074,5 & 535,7 & 500,4 \\
\hline 2005 & 752,9 & 1053,5 & 1250,9 & 1018,2 & 1407,9 & 1504,8 & 1215,2 & 1601,4 & 1128,1 & 865,4 & 695,4 & 1228,2 \\
\hline 2006 & 953,2 & 1004,8 & 1387,2 & 1247,5 & 826,2 & 1467,2 & 1694,9 & 1636,1 & 1077,5 & 1208,9 & 1112,1 & 261,6 \\
\hline 2007 & 459,4 & 807,9 & 981,1 & 730,6 & 1246,2 & 1250,3 & 1501,6 & 1581,0 & 1523,0 & 511,4 & 1209,0 & 1040,1 \\
\hline 2008 & 981,4 & 1157,7 & 494,6 & 711,3 & 1682,1 & 1450,9 & 1674,4 & 1371,2 & 1059,4 & 1043,0 & 819,5 & 875,1 \\
\hline 2009 & 768,2 & 1024,9 & 801,6 & 854,0 & 1707,2 & 1760,9 & 1459,8 & 1397,8 & 1510,1 & 1233,1 & 599,8 & 810,6 \\
\hline 2010 & 667,7 & 846,7 & 1097,9 & 906,7 & 1385,9 & 1569,5 & 1403,3 & 1165,4 & 998,1 & 1341,7 & 1193,7 & 1019,5 \\
\hline 2011 & 643,1 & 676,0 & 713,4 & 683,0 & 686,2 & 1032,7 & 1753,4 & 1358,6 & 1008,8 & 965,5 & 550,7 & 786,8 \\
\hline 2012 & 1476,2 & 1161,2 & 1124,0 & 961,6 & 1534,1 & 1735,4 & 1349,6 & 1469,6 & 1472,3 & 995,5 & 668,3 & 602,6 \\
\hline 2013 & 1175,6 & 1278,4 & 1574,0 & 1672,4 & 1598,4 & 1368,3 & 1333,9 & 1253,0 & 1521,5 & 1563,0 & 1731,4 & 1814,7 \\
\hline 2014 & 1786,4 & 1838,5 & 1891,5 & 1870,4 & 1871,1 & 1907,9 & 1938,1 & 1946,4 & 1901,3 & 1886,0 & 1602,3 & 1619,2 \\
\hline 2015 & 1823,9 & 1576,8 & 1543,0 & 1332,0 & 1522,7 & 1368,8 & 1873,0 & 1735,0 & 1590,9 & 1364,2 & 574,7 & 420,0 \\
\hline 2016 & 461,2 & 664,8 & 1147,1 & 1528,6 & 1509,2 & 1255,9 & 1618,5 & 1811,7 & 1895,1 & 1883,6 & 1601,1 & 1648,0 \\
\hline 2017 & 1517,9 & 1457,9 & 673,3 & 1228,7 & 1183,5 & 1694,2 & 1686,6 & 1343,3 & 1187,2 & 1735,1 & 1411,0 & 1173,2 \\
\hline 2018 & 1391,9 & 1723,0 & 1480,4 & 1502,9 & 1607,8 & 1581,8 & 1729,6 & 1823,4 & 1654,6 & 1038,2 & 1234,4 & 949,0 \\
\hline
\end{tabular}

Tabel 5. Sifat KBDI Bulanan Stasiun Hujan Batu Bersurat

\begin{tabular}{|c|c|c|c|c|c|c|c|c|c|c|c|c|}
\hline Tahun & Jan & Feb & Mar & Apr & Mei & Jun & Jul & Agu & Sep & Okt & Nov & \\
\hline 2004 & & $\mathrm{NDAH}$ & $\overline{\mathrm{DAI}}$ & ENDAH & & & & & & & $\pi$ & \\
\hline & & & & & & & & & & & & \\
\hline & & & & & & & & & & & & \\
\hline 00 & N & $\bar{N}$ & $\mathrm{EN}$ & $\mathrm{H}$ & & & & & & & & \\
\hline & & $\bar{D}$ & & & & & & & & & & \\
\hline 00 & 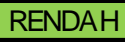 & $\mathrm{D}$ & -1 & -1 & & & & & & & & \\
\hline 010 & $\mathrm{NL}$ & ENL & $\mathrm{ED}$ & $2 \mathrm{ENL}$ & & & ED & $\mathrm{EI}$ & $\mathrm{EN}$ & & & $\mathrm{JG}$ \\
\hline 01 & 7 & $\underline{\mathrm{N}}$ & N & 2EE & & - & - & & 트 & & & $\mathrm{AH}$ \\
\hline$\leq$ & $\bar{G}$ & $\bar{D} f$ & $=\mathrm{D}$ & REM & & & $\mathrm{G}$ & $\mathrm{G}$ & $\overline{E D}$ & & $\mathrm{RE}$ & REN \\
\hline 2013 & DANG & EDA & TINGGI & TINGGI & ins & JG & $\mathrm{ED}$ & $\mathrm{ED}$ & TINGGI & & & $\mathrm{RIM}$ \\
\hline 01 & SIRIM & EKSTRIN & 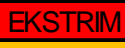 & KSTRIM & & & IIVI & & EKSTRIN & & & \\
\hline 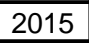 & KCTPIM & TINGC & TINGGI & SEDANG & TINGC & EDANG & $\overline{I V C}$ & TINC & TINGGI & & $\mathrm{AH}$ & RENDAH \\
\hline 2016 & RENDAH & RENDAH & SEDAN & TINGGI & $\overline{V C}$ & SED & & EKSTRIM & EKSTRIM & $E K S$ & TIN & TINGGI \\
\hline 2017 & & EDf & & ED & & & & & SEI & & $\mathrm{JG}$ & $\mathrm{VG}$ \\
\hline & & & & & & $T=$ & IINGGI & 10 & Thang & SED & CIDM & קחי \\
\hline
\end{tabular}

Perhitungan yang sama dilakukan untuk semua stasiun hujan yang ada di sekitar DAS Kampar.

\section{Analisis Spasial Indeks Kekeringan}

Analisis spasial indeks kekeringan ini dilakukan setelah nilai indeks kekeringan di semua titik stasiun hujan yang berada di sekitar DAS Kampar dianalisa untuk mengetahui sebaran kekeringannya. Nilai indeks kekeringan bulanan tiap-tiap stasiun hujan dihitung nilairata-rata bulanannya selama 15 (lima belas) tahun, yaitu dari tahun 2004 sampai dengan tahun 2018. Analisis spasial rata-rata bulanan DAS Kampar dapat dilihat pada Gambar 2 di bawah ini. (a)

(b)

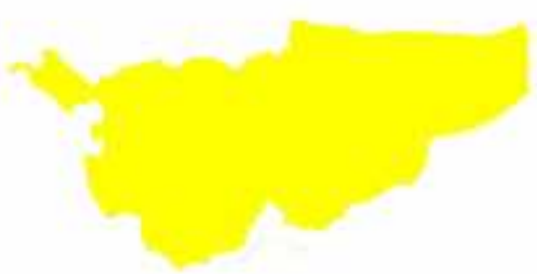

(c) 


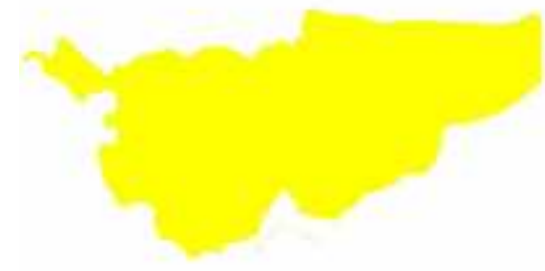

(d)

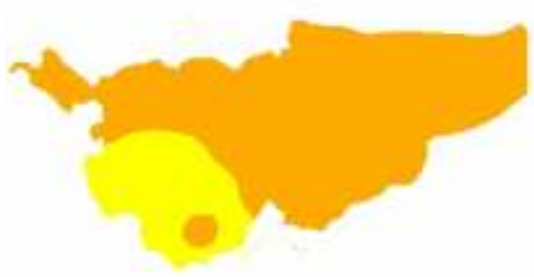

(g)

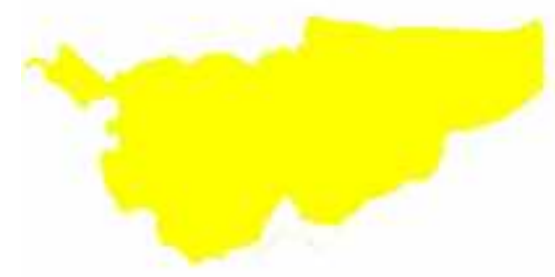

(j)

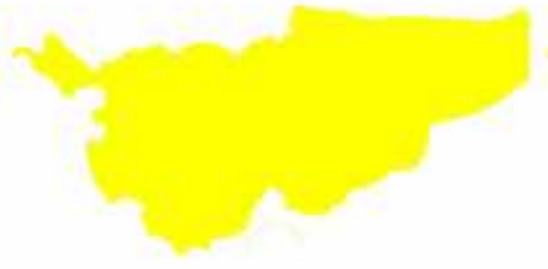

(e)

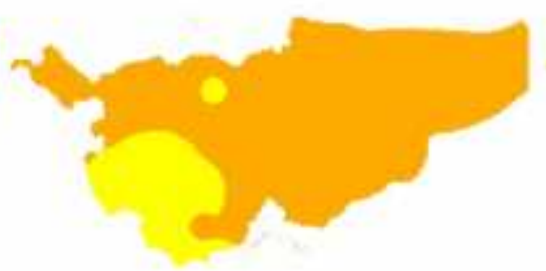

(h)

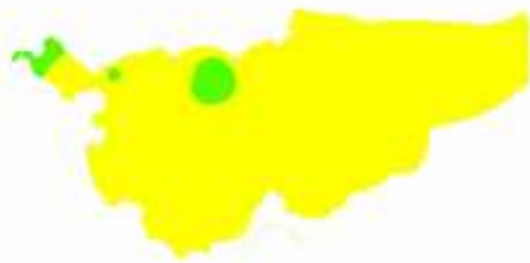

(k)

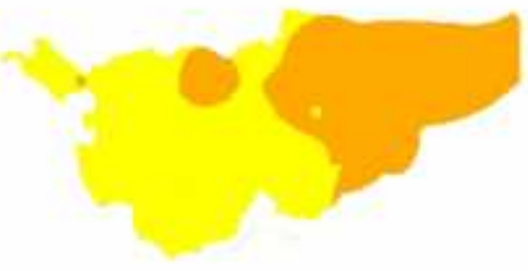

(f)

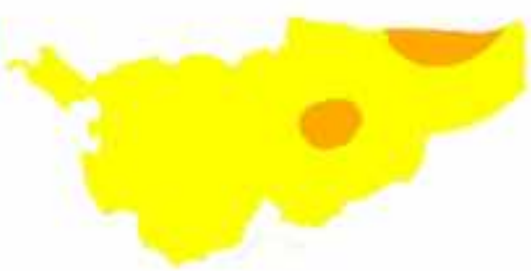

(i)

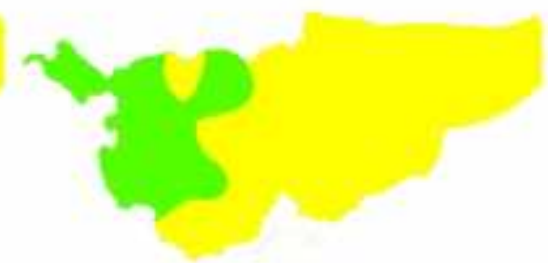

(l)

$$
\begin{aligned}
& \text { Rendah } \\
& \text { Sedang } \\
& \text { Tinggi } \\
& \text { Ekstrim }
\end{aligned}
$$

Gambar 2. Sebaran kekeringan rata-rata bulanan (2004-2018) di lokasi penelitian

(a) Januari, (b) Februari, (c) Maret, (d) April, (e) Mei, (f) Juni, (g) Juli,

(h) Agustus, (i) September, (j) Oktober, (k) November, (l) Desember

Gambar 2 di atas adalah sebaran KBDI rata-rata bulanan dari tahun 2004-2018 di lokasi penelitian, yaitu DAS Kampar. Dari gambar tersebut terlihat bahwa DAS Kampar mengalami 3 (tiga) sifat kekeringan yaitu "Rendah", "Sedang", dan "Tinggi". Terlihat juga bahwa tidak terjadi kekeringan "Ekstrim". Kekeringan dengan kategori "Tinggi" dimulai pada bulan Juni dan berakhir di bulan September, dengan sebaran kekeringan "Tinggi" terbesar terjadi pada bulan Juli dan Agustus. Sementara kekeringan dengan kategori "Rendah" terjadi pada bulan November dan Desember. Selain bulan-bulan tersebut, DAS Kampar didominasi oleh kekeringan "Sedang".

\section{KESIMPULAN}

Kesimpulan yang didapat dari penelitian ini antara lain:

1. Indeks kekeringan Metode KBDI DAS Kampar menunjukkan hasil bahwa sifat kekeringan di lokasi penelitian didominasi oleh sifat "Sedang".

2. Kekeringan dengan kategori "Tinggi" dimulai pada bulan Juni dan berakhir di bulan September dengan sebaran kekeringan "Tinggi" terbesar terjadi pada bulan Juli dan Agustus

3. Pada DAS Kampar tidak terjadi kekeringan "Ekstrim"

4. Kekeringan dengan kategori "Rendah" terjadi pada bulan November dan Desember

\section{REFERENSI}

Aprilliyanti, Titi dan Zainuddin, Muhammad, (2017), Pemetaan Potensi Kekeringan Lahan se-pulau Batam menggunakan Teknik Sistem Informasi Geografis (SIG) dan Penginderaan Jauh, Majalah Geografi Indonesia Vol. 31 No. 1.

Aronoff, S, (1989), Geographic Information Systems: A Management Perspective, Geocarto International, 4:4, 58

BNPB (Badan Nasional Penanggulangan Bencana), (2018), Antisipasi dan Pemetaan Potensi "Bencana Iklim" di Indonesia, Diskusi 
Multi Pihak"Pojok Iklim" Kementrian Lingkungan Hidup dan Kehutanan 2018.

Darfia, Novreta Ersyi., Kusuma, M. Syahril Badri., dan Kuntoro, Arno Adi, (2016), Analisis Indeks Kekeringan di DAS Rokan Provinsi Riau Menggunakan Data CFSR, Jurnal Rab Construction Research, Volume 1, No 2, Desember 2016.

Deeming, J. E, (1995), Pengembangan Sistem Penilaian Kebakaran Hutan di Propinsi Kalimantan Timur, Laporan Akhir Disampaikan kepada Deutsche Desellschaft Fuer Technische Zusammenaebeit (GTZ) GmbH. Postfach 518065726 Eschborn : Republik Federal Jerman.

Department of Fire \& Emergency Services (DFES), (2014), What is the Keetch-Byram Drought Index?, Government of Western Australia.

ESRI, (1990), Understanding GIS-The Arc/Info Method, A Workbook on Geographical ESRI, Redlands.

Gibson, Abraham J. et al, (2019), Catchment-Scale Drought: Capturing the Whole Drought Cycle Using Multiple Indicators, Hydrology and Earth System Sciences.

Keele, (1997), An Introduction to GIS using ArcView Tutorial, Issue 1. Keele University.

Keetch, J. J., and G. M. Byram, (1968), A Drought Index for Forest Fire Control, USDA Forest Service Research Paper SE-38.

Keetch, J. J. Byram, (1988), A Drought Index for Forest Control. US Department of Agriculture Forest Science Southestern Forest Experiment Station Asheville. North Carolina.

Kwak, Jaewon. et al, (2016), Assessment of Meteorological Drought in Korea under Climate Change, Hindawi Publishing Corporation Advances in Meteorology Volume 2016, Article ID 1879024, 13 pages.

Niemeyer, Stefan, (2008), New Drought Indices, Institute for Environment and Sustainability, Italy.

Ningsih, Dewi Handayani Untari., Soelistijadi, R., dan Sunardi, (2005), Pemanfaatan Analisis Spasial untuk Pengolahan Data Spasial Sistem Informasi Geografis, Jurnal Teknologi Informasi DINAMIK Volume X, No.2 Mei 2005 : 108-116

Prahasta, Eddy, (2009), Sistem Informasi Geografis Konsep-Konsep Dasar, Bandung: Informatika Bandung.

Raharjo, P. D, (2011), Teknik Penginderaan Jauh dan Sistem Informasi Geografis untuk Identifikasi Potensi Kekeringan, MAKARA of Technology Series, 14(2).

Susilo, Bowo, (2012), Aplikasi Pemetaan dan Analisis Spasial untuk Kajian Potensi Ternak Ruminansia Kecil di Kabupaten Kulonprogo, Jurnal Pendidikan Geografi, Volume 12, Nomor 2, Oktober 2012, halaman 61-70.

Tate, Laura, (2018), An Overview of GIS History. https://www.geospatialworld.net/blogs/overview-ofgis-history/

van Dijk. et al, (2013), The Millennium Drought in Southeast Australia (2001-2009): Natural and Human Causes and Implications for Water Resources, Ecosystems, Economy, and Society. Water Resources Research. 49 (2), 1040-1057, 2013.

Wilhite DA, dan Glantz $\mathbf{M H}$, (1985), Understanding the Drought Phenomenon: the Role of Definitions. Water Int 10:111-120.

Wu, Jiefeng. et al, (2016), Response of Hydrological Drought to Meteorological Drought under the Influence of Large Reservoir, Hindawi Publishing Corporation Advances in Meteorology Volume 2016, Article ID 2197142, 11 pages. 